\title{
Hydromorphological restoration stimulates river ecosystem metabolism
}

\author{
Benjamin Kupilas $^{1}$, Daniel Hering ${ }^{1}$, Armin W. Lorenz ${ }^{1}$, Christoph Knuth ${ }^{2}$, and Björn Gücker ${ }^{3}$ \\ ${ }^{1}$ Department of Aquatic Ecology, University of Duisburg-Essen, Universitätsstr. 5, 45141 Essen, Germany \\ ${ }^{2}$ Hydrogeology Department, Ruhr-Universität Bochum, Universitätsstr. 150, 44801 Bochum, Germany \\ ${ }^{3}$ Department of Geosciences, Applied Limnology Laboratory, Campus Tancredo Neves, \\ Federal University of São João del-Rei, 36301-360 São João del-Rei, MG, Brazil
}

Correspondence to: Benjamin Kupilas (benjamin.kupilas@uni-due.de)

Received: 11 October 201 - Discussion started: 31 October 2016

Revised: 20 February 2017 - Accepted: 13 March 2017 - Published: 12 April 2017

\begin{abstract}
Both ecosystem structure and functioning determine ecosystem status and are important for the provision of goods and services to society. However, there is a paucity of research that couples functional measures with assessments of ecosystem structure. In mid-sized and large rivers, effects of restoration on key ecosystem processes, such as ecosystem metabolism, have rarely been addressed and remain poorly understood. We compared three reaches of the third-order, gravel-bed river Ruhr in Germany: two reaches restored with moderate (R1) and substantial effort (R2) and one upstream degraded reach (D). Hydromorphology, habitat composition, and hydrodynamics were assessed. We estimated gross primary production (GPP) and ecosystem respiration (ER) using the one-station open-channel diel dissolved oxygen change method over a 50-day period at the end of each reach. Moreover, we estimated metabolic rates of the combined restored reaches $(\mathrm{R} 1+\mathrm{R} 2)$ using the two-station open-channel method. Values for hydromorphological variables increased with restoration intensity $(\mathrm{D}<\mathrm{R} 1<\mathrm{R} 2)$. Restored reaches had lower current velocity, higher longitudinal dispersion and larger transient storage zones. However, fractions of median travel time due to transient storage were highest in R1 and lowest in R2, with intermediate values in D. The share of macrophyte cover of total wetted area was highest in R2 and lowest in R1, with intermediate values in D. Station R2 had higher average GPP and ER than R1 and $\mathrm{D}$. The combined restored reaches $\mathrm{R} 1+\mathrm{R} 2$ also exhibited higher GPP and ER than the degraded upstream river (station D). Restoration increased river autotrophy, as indicated by elevated GPP:ER, and net ecosystem production
\end{abstract}

(NEP) of restored reaches. Temporal patterns of ER closely mirrored those of GPP, pointing to the importance of autochthonous production for ecosystem functioning. In conclusion, high reach-scale restoration effort had considerable effects on river hydrodynamics and ecosystem functioning, which were mainly related to massive stands of macrophytes. High rates of metabolism and the occurrence of dense macrophyte stands may increase the assimilation of dissolved nutrients and the sedimentation of particulate nutrients, thereby positively affecting water quality.

\section{Introduction}

River restoration is a pivotal element of catchment management to counteract anthropogenic degradation and depletion of river health and water resources, and to increase overall biodiversity and ecosystem services provisioning (Bernhardt et al., 2005; Strayer and Dudgeon, 2010). Based on legislative frameworks such as the EU Water Framework Directive (WFD) and the Clean Water Act in the United States, large investments have been made to restore rivers. In Europe, degraded river hydromorphology is considered one of the central impacts to the ecological status of rivers (EEA, 2012; Hering et al., 2015). For example, the German national river habitat survey, which evaluates 31 hydromorphological parameters for $100 \mathrm{~m}$ river sections, concluded that the majority of German rivers are severely degraded (Gellert et al., 2014; UBA, 2013). As the river biota depend on suitable habitats (Beisel et al., 2000; Schröder et al., 2013), about 
$85 \%$ of German rivers failed to reach the "good ecological status" demanded by the WFD (EEA, 2012). Accordingly, most restoration projects target the hydromorphological improvement of rivers. The majority of restoration measures is implemented at the reach scale, covering short river stretches typically of $1 \mathrm{~km}$ or less (Bernhardt et al., 2005; Palmer et al., 2014). A variety of reach-scale measures have been implemented (Lorenz et al., 2012): for instance, restoration activities along mountainous rivers in central Europe mainly targeted re-braiding and widening of streams, leading to greater habitat and hydrodynamic heterogeneity (Jähnig et al., 2009; Poppe et al., 2016). In combination with other characteristics of the river ecosystem - e.g., light, organic matter, nutrient availability, temperature, hydrologic and disturbance regimes - such hydromorphological changes likely affect biological community composition and ecosystem functioning, including ecosystem metabolism (Bernot et al., 2010; Tank et al., 2010).

The assessment of restoration effects has mainly focused on responses of aquatic organisms, such as fish (e.g., Roni et al., 2008; Haase et al., 2013; Schmutz et al., 2016), benthic invertebrates (e.g., Jähnig et al., 2010; Friberg et al., 2014; Verdonschot et al., 2016), and macrophytes (e.g., Lorenz et al., 2012; Ecke et al., 2016). Recently, increasing attention has also been given to the response of floodplain organisms (e.g., Hering et al., 2015; Göthe et al., 2016; Januschke and Verdonschot, 2016), while functional characteristics, i.e., the rates and patterns of ecosystem processes, have rarely been addressed. Ecosystem functions are life-supporting processes that are directly linked to ecosystem services, i.e., the benefits people obtain from the environment (Palmer and Filoso, 2009). Thus, an emerging interest in river restoration research is to incorporate the recovery of ecological functioning (Palmer et al., 2014). However, few studies have considered the response of river ecosystem functioning and functional metrics to restoration (e.g., Lepori et al., 2005; Bunn et al., 2010; Kupilas et al., 2016). Consequently, the effects of restoration on key ecosystem processes remain poorly understood.

Ecosystem metabolism, i.e., the combination of gross primary production (GPP) and ecosystem respiration (ER), is a fundamental ecosystem process in rivers. Ecosystem metabolism is a measure of the production and use of organic matter within a river reach by all biota. Therefore, it provides key information about a river's trophic and energetic base (relative contribution of allochthonous and autochthonous carbon) (Young et al., 2008; Tank et al., 2010; Beaulieu et al., 2013). The majority of stream ecosystem metabolism work has investigated natural changes, such as effects of floods and droughts (e.g., Uehlinger, 2000), seasonal or interannual changes (e.g., Uehlinger, 2006; Beaulieu et al., 2013), interbiome differences (e.g., Mulholland et al., 2001), or landuse change (e.g., Gücker et al., 2009; Silva-Junior et al., 2014). The majority of these studies have focused on smaller streams, while only few studies have measured metabolism of larger streams and rivers (e.g., Uehlinger, 2006; Dodds et al., 2013; Hall et al., 2015, 2016). The response of stream metabolism to hydromorphological changes, e.g., through river widening, is almost unknown, especially for larger rivers (but see Colangelo, 2007).

The widening of the riverbed enhances habitat complexity and diversity of the river channel and the riparian zone (Jähnig et al., 2010; Januschke et al., 2014; Poppe et al., 2016). Moreover, channel widening also favors macrophytes and other autotrophs through the creation of shallow, slowflowing areas and backwaters (Lorenz et al., 2012). Further, it increases light availability and water temperature, which have been identified as major factors controlling river metabolism, especially primary production (Uehlinger, 2006; Bernot et al., 2010; Tank et al., 2010). Accordingly, these changes potentially lead to enhanced in-stream autotrophic processes.

Restoration also increases the retention of allochthonous organic matter (Lepori et al., 2005, 2006; Flores et al., 2011). Moreover, the reconnection of rivers with their floodplains by creating shallower river profiles and removing bank fixations may enhance inundation frequency, and hence resource transfers from land to water. In combination, these changes can favor heterotrophic activity in the river. Restoration also affects hydrodynamics and surface water-ground water interactions of streams (Becker et al., 2013): for instance, widening of the stream channel reduces flow velocity and the creation of backwaters and pools possibly leads to changes in the size and location of transient storage zones (Becker et al., 2013). Increases in transient storage zones potentially enhance ER (Fellows et al., 2001) and nutrient processing (Valett et al., 1996; Gücker and Boëchat, 2004).

The objective of this study was to quantify reach-scale restoration effects on hydromorphology, habitat composition, and hydrodynamics, as factors potentially affecting river ecosystem function, by comparing three contiguous stream reaches (two restored and one upstream non-restored reach) of a mid-sized mountain river in Germany and to determine the corresponding responses of river metabolism. We expected (i) hydromorphological river characteristics, i.e., habitat composition and hydrodynamics, to change following restoration, with the magnitude of change depending on restoration effort (e.g., width and diversity of the river channel, and abundance of primary producers, as well as sizes and locations of transient storage zones in the two restored river reaches compared to the degraded reach), and (ii) ecosystem metabolism to respond with increased metabolic rates, i.e., enhanced GPP and ER, mainly as a result of increased abundances of primary producers. 


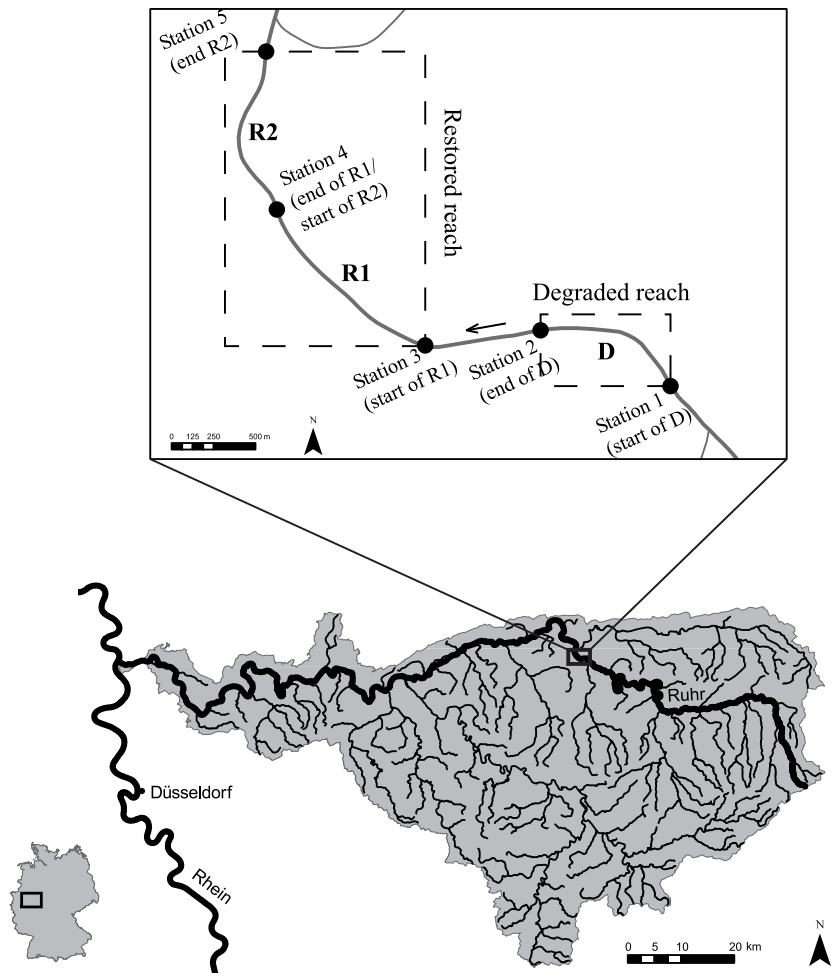

Figure 1. Location of the study site in the upper catchment of the river Ruhr in Germany. Stations represent start and end of the investigated river reaches (degraded, first restored and second restored reach).

\section{Methods}

\subsection{Study site}

This study was conducted in the upper river Ruhr (Federal State of North Rhine-Westphalia, Germany, Fig. 1, Table 1) a tributary to the Rhine. The third-order Ruhr is a mid-sized mountain river with gravel and cobbles as bed sediments. The catchment area upstream of the study site is $1060 \mathrm{~km}^{2}$, about $64 \%$ of which is forested, $28 \%$ is arable land and pasture, and $8 \%$ is urban area (located mainly in the floodplains). The study site is at an altitude of $153 \mathrm{~m}$ a.s.l. and the mean annual discharge was $21.3 \mathrm{~m}^{3} \mathrm{~s}^{-1}$ between 2004 and 2009 . The Ruhr is draining one of the most densely populated areas of Europe; however, population density of the upstream catchment area is low (135.3 inhabitants km-2 upstream of the study site). Due to manifold uses, the river's hydromorphology has been largely modified by impoundments, residual flow sections, bank fixation, and industrial and residential areas in the floodplain. More recently, the hydromorphology of several river sections has been restored.

Restoration aimed to establish near-natural hydromorphology and biota. Restoration measures were implemented between 2007 and 2009 and included the widening of the riverbed and the reconnection of the river with its flood-
Table 1. River and study site characteristics.

\begin{tabular}{|c|c|}
\hline \multicolumn{2}{|l|}{ River characteristics } \\
\hline Catchment size $\left(\mathrm{km}^{2}\right)$ & 4485 \\
\hline Stream length $(\mathrm{km})$ & 219 \\
\hline River type & Gravel bed \\
\hline Stream order & 3 \\
\hline Ecoregion & Central Highlands \\
\hline \multicolumn{2}{|l|}{ Study site characteristics } \\
\hline Latitude $(\mathrm{N})^{\mathrm{a}}$ & 51.44093 \\
\hline Longitude $(\mathrm{E})^{\mathrm{a}}$ & 7.96223 \\
\hline Catchment size $\left(\mathrm{km}^{2}\right)$ & 1060 \\
\hline Altitude (m a.s.l.) & 153 \\
\hline Mean annual discharge $\left(\mathrm{m}^{3} \mathrm{~s}^{-1}\right)$ & 21.3 \\
\hline Catchment geology & siliceous \\
\hline Restoration length (km) & 2.3 \\
\hline Restoration date & 2007-2009 \\
\hline Main restoration action & riverbed widening \\
\hline $\mathrm{pH}^{\mathrm{b}}$ & 8.3 \\
\hline Electric conductance ${ }^{\mathrm{b}}\left(\mu \mathrm{S} \mathrm{cm}^{-1}\right)$ & 340 \\
\hline Total nitrogen ${ }^{\mathrm{b}}\left(\mathrm{mg} \mathrm{L}^{-1}\right)$ & 2.7 \\
\hline $\mathrm{NO}_{3}-\mathrm{N}^{\mathrm{b}}\left(\mathrm{mg} \mathrm{L}^{-1}\right)$ & 2.53 \\
\hline $\mathrm{NH}_{4}-\mathrm{N}^{\mathrm{b}}\left(\mathrm{mg} \mathrm{L}^{-1}\right)$ & $<0.1$ \\
\hline Total phosphorus ${ }^{\mathrm{b}}\left(\mathrm{mg} \mathrm{L}^{-1}\right)$ & 0.07 \\
\hline Total organic carbon ${ }^{\mathrm{b}}\left(\mathrm{mg} \mathrm{L}^{-1}\right)$ & 2.3 \\
\hline
\end{tabular}

plain by creating a shallower river profile and by removing bank fixations. Moreover, the physical stream quality was enhanced by generating secondary channels and islands, adding instream structures, such as woody debris, and creating shallow habitats providing more space for autotrophs (see Sect. S1 in the Supplement).

We separated the restored reach into two reaches of approximately similar lengths $(1210$ and $1120 \mathrm{~m})$ with obvious differences in morphological stream characteristics due to differing restoration effort (R1: moderate restoration effort; R2: high restoration effort). Briefly, in R2 a larger amount of soil was removed and the costs for the implementation of measures were higher than in R1 (see Sect. S1). In R2 the bank fixation was removed at both shorelines and the river was substantially widened and secondary channels and islands were created, while the removal of bank fixation and widening in R1 mainly focused on one side due to constrains posed by a nearby railroad (see Sect. S1). The restored reaches were compared to a degraded "control section" of $850 \mathrm{~m}$ length located upstream of the restored reaches (D). The degraded reach was characteristic for the channelized state of the river Ruhr upstream of the restoration site, and reflected the conditions of the restored sections prior to restoration: the reach was a monotonous, channelized and narrowed 
river section with fixed banks and no instream structures. A $650 \mathrm{~m}$ long river section separating the degraded from the restored river reach was excluded from the investigations, as its hydromorphology was deviating due to constructions for canoeing and a bridge. As the three sections were neighboring each other, differences in altitude, slope, discharge, and catchment land cover between reaches were negligible.

\subsection{Hydromorphology and habitat composition}

Physical stream quality was quantified from aerial photos. High-resolution photos of the restored reaches were taken in summer 2013 using a Falcon 8 drone (AscTec, Germany). Aerial photos of the degraded reach from the same year at similar discharge conditions were provided by the Ministry for Climate Protection, Environment, Agriculture, Conservation and Consumer Protection of the State of North RhineWestphalia. Photos were analyzed in a geographical information system (ArcGIS 10.2, ESRI). For each reach, we measured the width of the wetted channel every $20 \mathrm{~m}$ along cross-sectional transects at low flow conditions and calculated mean width and its variation (reach D: $n=42$; R1: $n=59 ; \mathrm{R} 2: n=54)$. For each reach, we recorded thalweg lengths, the area of the wetted stream channel, the floodplain area (defined as bank-full cross-sectional area), and the area covered by islands, woody debris, and aquatic macrophyte stands (Fig. 2). Subsequently, the share of macrophyte stands of the total wetted area was calculated for each reach. Additionally, macrophytes were surveyed according to the German standard method (Schaumburg et al., 2005a, b) in summer 2013. A $100 \mathrm{~m}$ reach was investigated by wading through the river in transects every $10 \mathrm{~m}$, and walking along the riverbank (Lorenz et al., 2012). All macrophyte species were recorded and species abundance was estimated following a five-point scale developed by Kohler (1978), ranging from 1 ("very rare") to 5 ("abundant, predominant"). The empirical relationship between the values of the five-point Kohler scale $(x)$ and the actual surface cover of macrophytes $(y)$ is given by the function $y=x^{3}$ (Kohler and Janauer, 1997; Schaumburg et al., 2004). Using this relationship, we $x^{3}$-transformed the values of the Kohler scale into quantitative estimates of macrophyte cover for the studied $100 \mathrm{~m}$ reaches.

\subsection{Hydrodynamics}

Stream hydrodynamics were estimated using a conservative tracer addition experiment with the fluorescent dye amidorhodamine G. Across the river width, we injected the dissolved dye in a distance sufficiently upstream to the first study reach to guarantee complete lateral mixing at the first sampling station. Breakthrough curves of the tracer were continuously measured in the main current at the upstream and downstream ends of all three reaches (Fig. 1). Concentration of dye was recorded at a resolution of $10 \mathrm{~s}$ at the most upstream and downstream sampling stations using field fluorometers (GGUN-FL24 and GGUN-FL30, Albillia, Switzerland). At the other sampling stations (start and end of each investigated river reach) water samples were taken manually at 2 min intervals. The samples were stored dark and cold in the field and subsequently transported to the hydrogeochemical laboratory of the Ruhr University Bochum. Amidorhodamine $G$ concentrations of water samples were measured with a fluorescence spectrometer (Perkin Elmer LS 45; detection limit of $0.1 \mathrm{ppb}$ ) and standard calibration curves prepared from the tracer and river water. Field fluorometers were calibrated prior to experiments with the same standard calibration procedure.

Subsequently, we used the one-dimensional solute transport model OTIS-P (Runkel, 1998) to estimate parameters of river hydrodynamics for each reach from the breakthrough curves: advective velocity, longitudinal dispersion, stream channel and storage zone cross-sectional areas, and storage rate. We further calculated fractions of median travel time due to transient storage $\left(F_{\text {med }}{ }^{200}\right)$ based on the hydrodynamic variables obtained from transport modeling (Runkel, 2002). Additionally, Damköhler numbers were estimated for each reach (Harvey and Wagner, 2000).

\subsection{Discharge}

Discharge data were provided by the North RhineWestphalia State Agency for Nature, Environment and Consumer Production, Germany (Landesamt für Natur, Umwelt und Verbraucherschutz Nordrhein-Westfalen) for a gauging station situated at the downstream end of the study site. At this station, discharge was constantly recorded at 5 min intervals.

\subsection{Ecosystem metabolism}

We estimated river dissolved $\mathrm{O}_{2}$ (DO) metabolism using the "open-channel one-station and two-station diel DO change techniques" (Odum, 1956; Marzolf et al., 1994; Young and Huryn, 1998; Roberts et al., 2007). We initially chose the one-station method to estimate metabolic rates at the downstream end of each reach (stations D, R1, and R2), as the individual studied reaches were too short for a reliable estimation of ecosystem metabolism with the two-station technique, due to high current velocities and low reaeration rates. According to Demars et al. (2015), the two-station method is applicable to reach lengths 0.4 to $1.0 \mathrm{v} / \mathrm{k}$. For our reaches of the Ruhr, this range corresponds to $3283-8280 \mathrm{~m}$ for reach D, 2765$6912 \mathrm{~m}$ for reach R1, 1624-4061 m for reach R2, and 2199$5497 \mathrm{~m}$ for the combined reach R1 + R2. Thus, the quantification of metabolism using the two-station method was only possible for the combined reach $\mathrm{R} 1+\mathrm{R} 2$ with a reach length of $2330 \mathrm{~m}$.

Reach lengths influencing the one-station diel dissolved $\mathrm{O}_{2}$ change technique in our study were typically much longer 


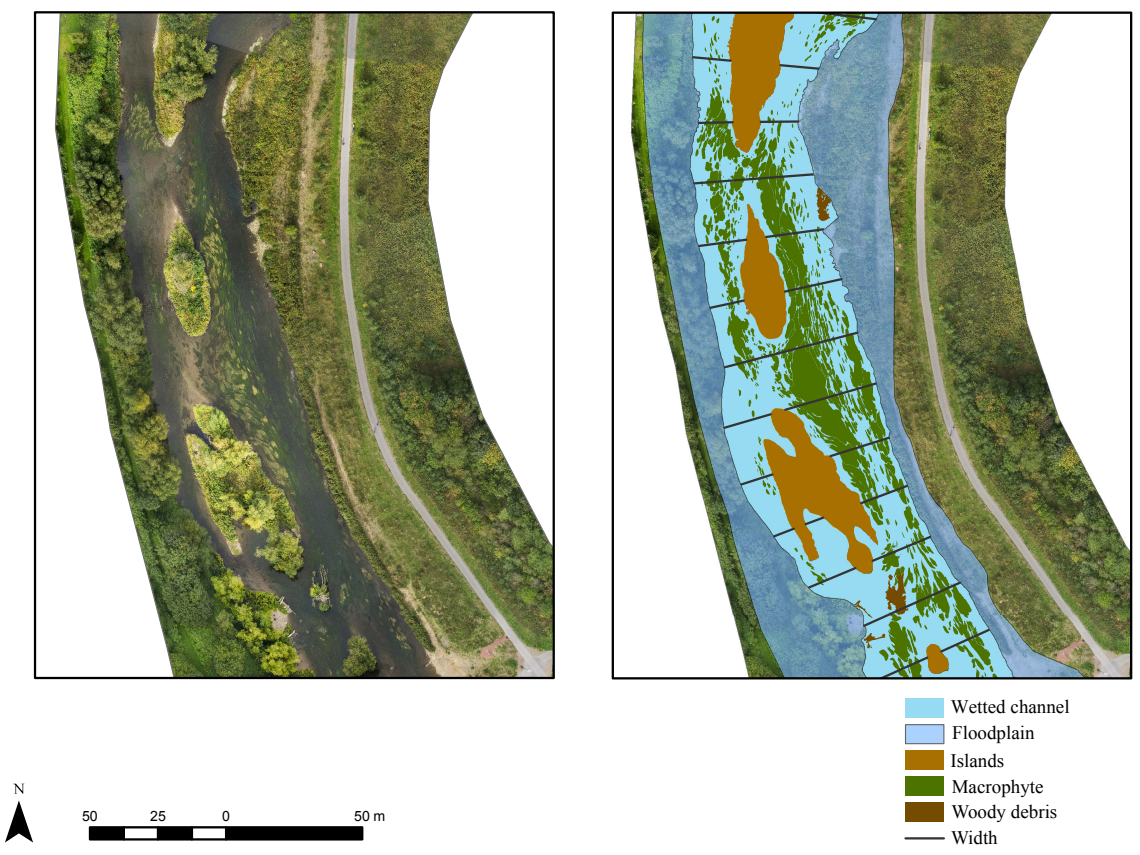

Figure 2. Analysis of aerial photos. A representative river section of the second restored reach is shown.

than the experimental reaches, due to high current velocities and low reaeration $(>10 \mathrm{~km}$; estimated according to Chapra and Di Toro, 1991). Following methods in Demars et al. (2015), metabolism estimates at the downstream sampling station R2 were only to $35 \%$ influenced by the restored river sections, but to $65 \%$ by upstream degraded river sections. Accordingly, differences in metabolic rates among sampling stations at the end of restored and impacted experimental reaches as estimated in our study should be viewed as qualitative indicators of restoration effects, rather than measured metabolic rates of the experimental reaches. To quantitatively support our qualitative findings, we additionally used the two-station method for the combined restored river reach $\mathrm{R} 1+\mathrm{R} 2$, which was long enough for the application of the two-station open-channel method. The selected methods are based on the assumption that changes in DO within a parcel of water traveling downstream can be attributed to metabolism (photosynthesis and respiration) and to gas exchange between water and atmosphere, given that no significant groundwater dilution of river water occurs along the studied river:

$\mathrm{dDO} / \mathrm{d} t=\mathrm{GPP}-\mathrm{ER}-\left(K_{\text {oxy }} D\right)$,

where $\mathrm{dDO} / \mathrm{d} t$ is the change in dissolved oxygen concentration ( $\mathrm{mg} \mathrm{O}_{2} \mathrm{~L}^{-1} \mathrm{~s}^{-1}$ ), GPP is the gross primary production $\left(\mathrm{mg} \mathrm{O}_{2} \mathrm{~L}^{-1} \mathrm{~s}^{-1}\right)$, ER is the ecosystem respiration $\left(\mathrm{mg} \mathrm{O}_{2} \mathrm{~L}^{-1} \mathrm{~s}^{-1}\right), K_{\text {oxy }}$ is the reaeration coefficient $\left(\mathrm{s}^{-1}\right)$, and $D$ is the oxygen deficit or surplus in the river (i.e., the difference between the measured oxygen concentration and the value at saturation; $\mathrm{mg} \mathrm{O}_{2} \mathrm{~L}^{-1}$ ). The change in $\mathrm{DO}$ was estimated as the difference between consecutive 5 min readings of the same probe for the one-station method and as the difference between upstream (top of reach R1) and downstream probes (end of reach R2) for the two-station method (Roberts et al., 2007; Beaulieu et al., 2013).

In two consecutive field campaigns in summer 2014, DO and water temperature were continuously measured at the downstream ends of the three reaches and at the top of reach R1 at 5 min intervals for 50 days. The DO probes with data loggers $\left(\mathrm{O}_{2}\right.$-Log3050-Int data logger, Driesen + Kern $\mathrm{GmbH}$, Germany) were installed in the thalweg of the river in the middle of the water column. The DO probes were calibrated in water-saturated air prior to measurements. Additionally, probes were cross-calibrated for $1 \mathrm{~h}$ at a single sampling station in the river before and after the measurements. We used the data of this comparison to correct for residual differences among probes (Gücker et al., 2009). This procedure assured that differences between probes were only due to differences in DO and water temperatures and not to analytical errors. In previous laboratory tests, the probes showed no drift and were thus not corrected for drift during the measurement campaigns (Almeida et al., 2014).

In parallel to DO and water temperature, atmospheric pressure was recorded (Hobo U20-001-04; Onset Computer Corporation). We used atmospheric pressure and water temperature data to calculate the oxygen saturation. Reaeration coefficients $\left(K_{\text {oxy }}{ }^{20}\right.$; standardized for $\left.20^{\circ} \mathrm{C}\right)$ were estimated using the nighttime regression approach (Young and Huryn, 1999). For the downstream stations of all three sampling reaches, we calculated reaeration coefficients $\left(K_{\text {oxy }}\right)$ as the slope of regressions between DO change rates $(\mathrm{dDO} / \mathrm{d} t$; 


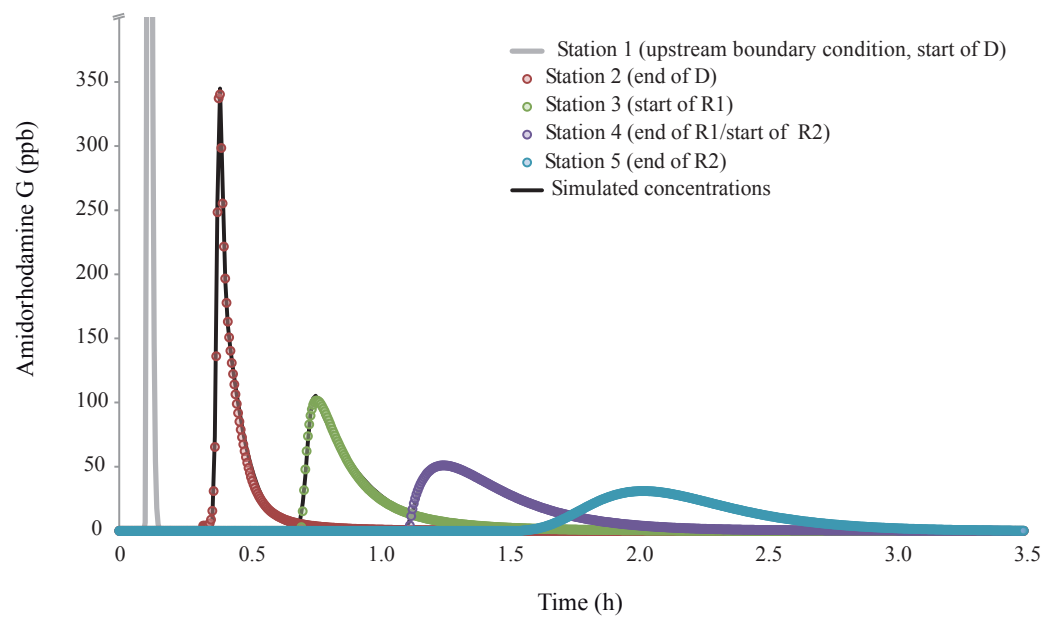

Figure 3. Tracer breakthrough curves for the conservative tracer addition experiment in the river Ruhr. Upstream boundary condition based on concentrations at sampling station 1 (start of degraded reach, D, grey solid line), observed concentrations at sampling stations 2 (end of degraded reach, empty circles), 3 (start of first restored reach, R1, empty squares), 4 (end of first restored reach, start of second restored reach, R2, empty triangles), 5 (end of second restored reach, crosses), and simulated concentrations based on final parameter estimates with OTIS-P (solid lines).

$\left.\mathrm{mg} \mathrm{O}_{2} \mathrm{~L}^{-1} \mathrm{~s}^{-1}\right)$ and DO deficits $\left(D ; \mathrm{mg} \mathrm{O}_{2} \mathrm{~L}^{-1}\right)$ at night (night hours were defined as the period $1 \mathrm{~h}$ after sunset to $1 \mathrm{~h}$ before sunrise):

$\mathrm{dDO} / \mathrm{d} t=K_{\text {oxy }} D+\mathrm{ER}$.

We only considered significant nighttime regressions $(P<$ $0.05)$. Reaeration coefficients for days without significant regressions were estimated as the average value of the coefficients of the days before and after, as we did not observe $K_{\text {oxy }}{ }^{20}$ - discharge relationships in our data (see Sect. S2) that could have been used to estimate $K_{\text {oxy }}{ }^{20}$ values for days without reliable estimates. Estimated reaeration coefficients were low and ranged from 5 to $15 \mathrm{day}^{-1}$ in our study (see Sect. S2). Subsequently, we calculated ER and GPP as described in detailed elsewhere (Marzolf et al., 1994; Young and Huryn, 1998; Roberts et al., 2007) from the recorded nighttime river water DO deficit and the daytime DO production, respectively, corrected for atmospheric reaeration (see Sect. S3). Metabolic rates obtained by this method closely matched those obtained with the estimator of Reichert et al. (2009). Ground water dilution was not detected, i.e., discharge differences among the investigated river reaches were within the ranges of method uncertainty of discharge measurements, and was thus not considered into our estimates. Metabolism measurements from days at which floating macrophytes accumulated around probes and affected DO measurements were eliminated from the dataset.

\subsection{Data analysis}

We used the ARIMA function in R to identify an ARIMA model that best represented all time series (metabolic parameters at stations D, R1, R2, and reach R1 + R2), estimated average parameter predictions and $95 \%$ confidence limits for each time series based on these models, and used $F$ tests to test the hypothesis of differences among time series (compare Roley et al., 2014). Data recorded at the time of flooding events were omitted from analyses because GPP was not detectable, and we cannot be sure whether GPP was indeed zero or very low or whether high flows prevented the detection of GPP. Overall, data of $n=32$ days were used in the analyses. Repeated measures ANOVAs and Tukey's HSD post hoc tests were used to test for differences in water temperature among river reaches. Conventional one-way ANOVA was used to test for differences in river width, comparing the transect measurements performed in the three river reaches. All statistical analyses were conducted in R (R Development Core Team, 2007).

\section{Results}

\subsection{Hydromorphology and habitat composition}

Restored river reaches were morphologically more complex and had significantly wider wetted channels (ANOVA and Tukey post hoc test, $P<0.05$ ) and more variable channel width than the degraded reach (Table 2). Furthermore, the restored reaches had larger wetted channel areas, floodplain areas, island areas, and patches of woody debris than the degraded river reach (Table 2 ). The intensively restored reach 
Table 2. Morphological and hydrodynamic characteristics of the investigated river reaches.

\begin{tabular}{|c|c|c|c|}
\hline Variable & $\begin{array}{l}\text { Degraded } \\
\text { reach }(\mathrm{D})\end{array}$ & $\begin{array}{r}\text { First restored } \\
\text { reach }(\mathrm{R} 1)\end{array}$ & $\begin{array}{r}\text { Second restored } \\
\text { reach }(\mathrm{R} 2)\end{array}$ \\
\hline Thalweg length (m) & 850 & 1210 & 1120 \\
\hline Width (m) & 22.5 & 28.2 & 36.6 \\
\hline Width variation ${ }^{\mathrm{a}}(\mathrm{m})$ & 3.3 & 6.3 & 10.5 \\
\hline Wetted channel area $\left(\mathrm{m}^{2}\right)$ & 19114 & 34604 & 41673 \\
\hline Floodplain area $\left(\mathrm{m}^{2}\right)$ & 27363 & 30630 & 34218 \\
\hline Island area $\left(\mathrm{m}^{2}\right)$ & 0 & 2666 & 12381 \\
\hline Woody debris $\left(\mathrm{m}^{2}\right)$ & 0 & 467 & 691 \\
\hline Macrophyte coverage $(\%)$ & 4.8 & 1.7 & 19.8 \\
\hline Flow velocity $\left(\mathrm{m} \mathrm{s}^{-1}\right)$ & 0.95 & 0.8 & 0.47 \\
\hline Longitudinal dispersion, $D\left(\mathrm{~m}^{2} \mathrm{~s}^{-1}\right)^{\mathrm{b}}$ & 0.28 & 0.59 & 10.21 \\
\hline Channel cross-sectional area, $A\left(\mathrm{~m}^{2}\right)^{\mathrm{b}}$ & 12.11 & 14.96 & 27.05 \\
\hline Storage zone cross-sectional area, $A_{\mathrm{S}}\left(\mathrm{m}^{2}\right)^{\mathrm{b}}$ & 2.38 & 4.48 & 3.16 \\
\hline Storage rate, $\alpha\left(\mathrm{s}^{-1}\right)^{\mathrm{b}}$ & $4.9 \times 10^{-4}$ & $7.4 \times 10^{-4}$ & $2.0 \times 10^{-4}$ \\
\hline Transient storage, $F_{\text {med }}{ }^{200}(\%)$ & 1.6 & 3.9 & 0.8 \\
\hline Damköhler number & 2.8 & 4.8 & 4.4 \\
\hline
\end{tabular}

${ }^{a}$ Width variation calculated as standard deviation; degraded: $n=42$; restored $1: n=59$; restored $2: n=54{ }^{\mathrm{b}}$ Data on hydrodynamic characteristics represent the final parameters obtained by one-dimensional transport modeling using OTIS-P.

R2 showed the highest values for hydromorphological variables (Table 2). The share of macrophyte cover of total wetted area was also highest in $\mathrm{R} 2$.

\subsection{Hydrodynamics}

The reaches differed in hydrodynamic parameters: the restored reaches had lower flow velocity and higher longitudinal dispersion, cross-sectional areas of the advective channel, and storage zone cross-sectional areas than the degraded reach (Table 2). Storage rate and fractions of median travel time due to transient storage $\left(F_{\text {med }}{ }^{200}\right)$ was highest in R1 and lowest in R2, with intermediate values for D (Table 2). Damköhler numbers between 0.5 and 5.0 indicated reliable transient storage parameter estimates for the reaches (Harvey and Wagner, 2000; Table 2). Tracer breakthrough curves estimated by transport modeling closely corresponded to measured tracer concentrations (Fig. 3).

\subsection{Discharge and water temperature}

Mean discharge during the first weeks of measurement was $8.4 \mathrm{~m}^{3} \mathrm{~s}^{-1}$. The hydrograph was characterized by a large summer flow peak and two minor peaks during the study period (Fig. 4a). During the flow peaks discharge rapidly increased 3.5- to 7-fold relative to the mean flow. Trends in water temperature over time were very similar for the three river reaches and are exemplarily shown for R2 (Fig. 4b). Overall, restored reaches had higher mean daily water temperatures than the degraded reach, with R2 having higher mean daily water temperatures compared to R1 (repeated measures ANOVA, $P<0.0001$; Tukey's HSD post hoc tests, $P<0.0005)$.

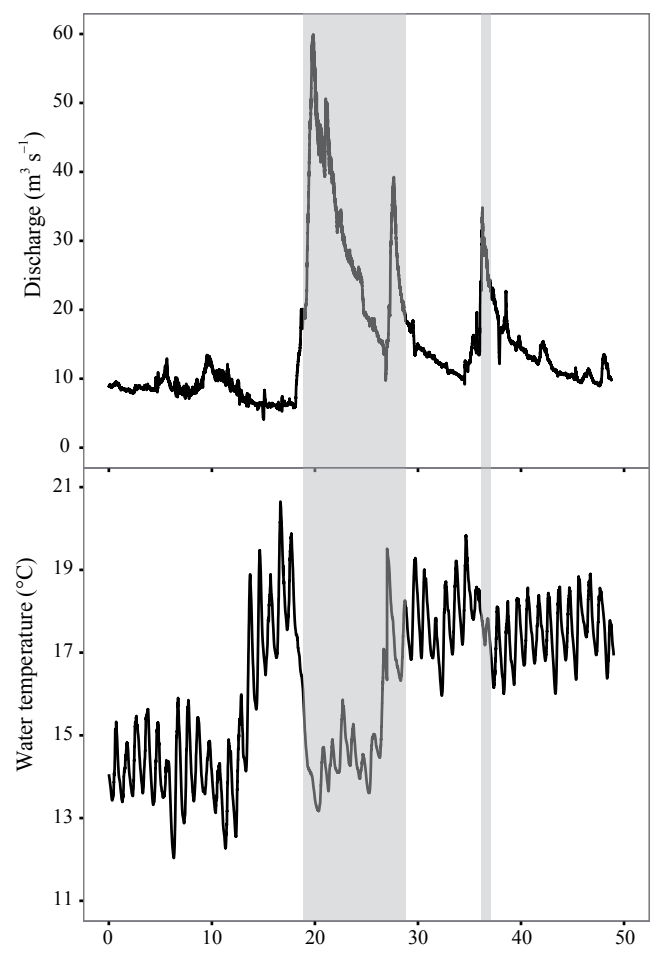

Figure 4. (a) Discharge and (b) water temperature in the river Ruhr during the study period in summer 2014. Trend in water temperature during study period is exemplarily shown for the second restored reach $(\mathrm{R} 2)$. 

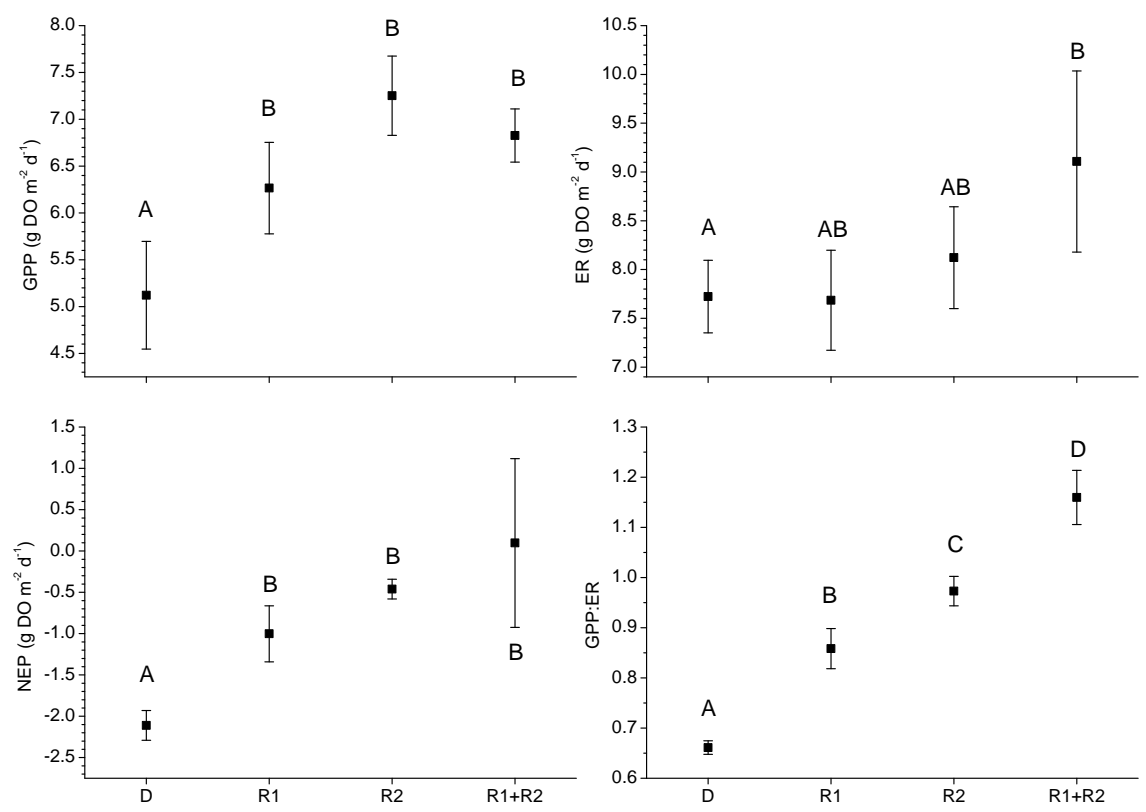

Figure 5. Average predicted metabolic parameters and $95 \%$ confidence intervals of time series estimated by the one-station open-channel method at river stations downstream of reaches D, R1, and R2, and by the two-station open-channel method for river reach R1 + R2. $F$ tests for all variables were significant (GPP: $P<0.001$; ER: $P<0.05$; NEP: $P<0.005$, GPP: ER: $P<0.0001$ ). Different letters indicate differences according to Tukey's post hoc test $(P<0.05)$.

\subsection{Ecosystem metabolism}

We observed significant effects of reach-scale restoration on metabolic rates estimated at the end of the restored river sections (R1 and R2 compared to D; estimated by the one-station method) and between the upstream degraded river (station $\mathrm{D}$ ) and the combined restored reaches R1 + R2 (estimated with the two-station method). According to the ARIMA function estimates, we found higher river GPP, net ecosystem production (NEP), and GPP: ER at the restored river sections ( $\mathrm{R} 1$ and $\mathrm{R} 2$ versus station $\mathrm{D}$; estimated with the one-station method; Fig. 5). Moreover, GPP, ER, NEP, and GPP : ER were also higher (Fig. 5) in the total restored river reach $(\mathrm{R} 1+\mathrm{R} 2$; estimated with the two-station method) than in the upstream degraded river (measured at section $\mathrm{D}$ with the onestation method). These findings indicate an increase in the river's metabolism following restoration.

The three sampling stations at the downstream ends of the reaches generally exhibited similar metabolism patterns (Fig. 6). Rates of GPP and ER ranged from 2.59 to 13.06 and -4.96 to $-17.52 \mathrm{~g} \mathrm{O}_{2} \mathrm{~m}^{-2} \mathrm{day}^{-1}$ at sampling station $\mathrm{D}$, from 2.33 to 12.36 and -4.04 to $-14.02 \mathrm{~g} \mathrm{O}_{2} \mathrm{~m}^{-2}$ day $^{-1}$ at station $\mathrm{R} 1$, and from 3.61 to 17.64 and -5.91 to $-24.71 \mathrm{~g} \mathrm{O}_{2} \mathrm{~m}^{-2}$ day $^{-1}$ at station R2. Daily rates of GPP were highest shortly before the main summer flow peak at all sampling stations (Fig. 6a). GPP was not detectable during the summer flow peaks. ER generally mirrored the GPP patterns, but showed distinct peaks at the beginning of the summer flow peak. ER exceeded GPP during all but one day at R1 and two days at R2. Consequently, NEP (net ecosystem production) was negative during most of the measured period, i.e., reaches were heterotrophic (Fig. 6b). NEP ranged from -4.61 to $-0.47 \mathrm{~g} \mathrm{O}_{2} \mathrm{~m}^{-2} \mathrm{day}^{-1}$ at station $\mathrm{D}$, from -4.29 to $0.22 \mathrm{~g} \mathrm{O}_{2} \mathrm{~m}^{-2} \mathrm{day}^{-1}$ at station $\mathrm{R} 1$, and from -8.24 to $0.14 \mathrm{~g} \mathrm{O}_{2} \mathrm{~m}^{-2}$ day $^{-1}$ at station $\mathrm{R} 2$. The average GPP : ER ratio ranged from 0.66 to 0.97 across all sampling stations, also indicating that the Ruhr was moderately heterotrophic. General patterns in daily rates of both GPP and ER also seemed to be influenced by flow peaks. GPP and ER were both suppressed immediately following the flooding events. The ensuing recovery patterns for GPP and ER were similar for all investigated sampling stations: depending on magnitude of flow, GPP and ER were suppressed for several days, but steadily returned to pre-disturbance conditions. The total restored river reach (R1 + R2, two-station method) showed temporal metabolism patterns comparable to those estimated at the three sampling stations with the one-station method (Fig. 6). However, NEP of the total restored river reach $(\mathrm{R} 1+\mathrm{R} 2)$ was positive and the average GPP: ER ratio was higher than 1 during most of the sampling period, indicating a slight change in the river's metabolic balance following restoration.

\section{Discussion}

Restoration of river hydromorphology usually covers short river stretches of less than $1 \mathrm{~km}$ and is expected to increase 
(a) Station 1

(downstream end of degraded reach $=\mathrm{D})$

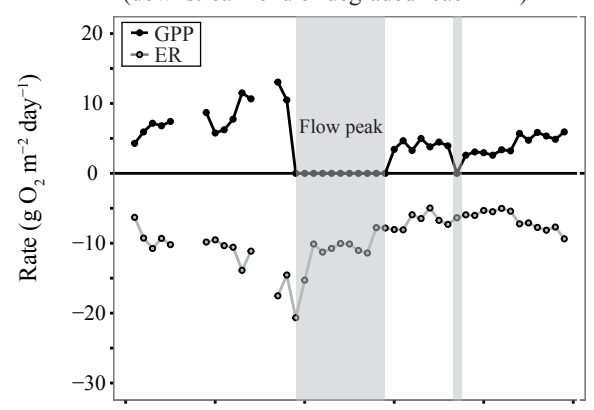

Station 2

(downstream end of 1 st restored reach $=\mathrm{R} 1)$

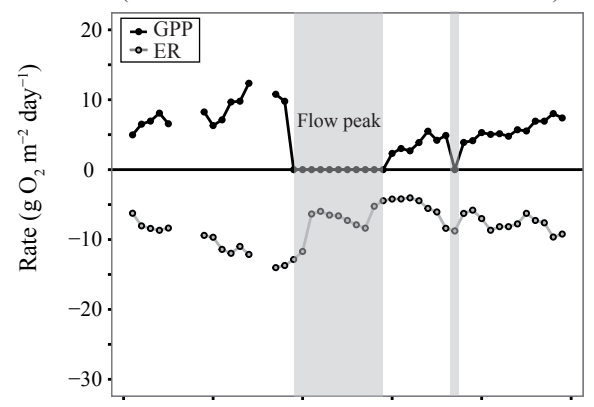

Station 3

(downstream end of 2 nd restored reach $=\mathrm{R} 2$ )
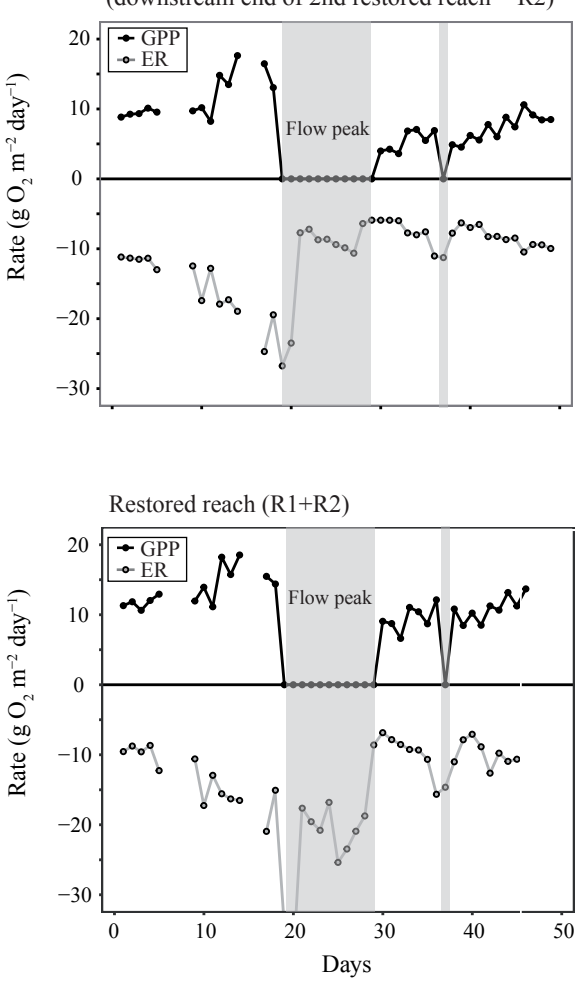

(b)
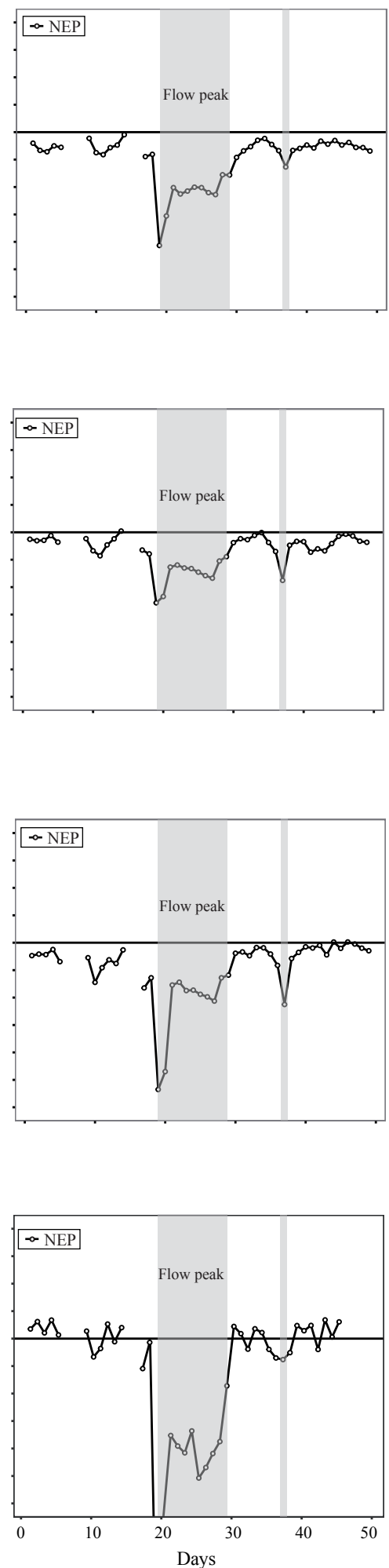

Figure 6. Daily rates of (a) gross primary production (GPP: positive values, black line) and ecosystem respiration (ER: negative values, grey lines) and (b) net ecosystem production (NEP) measured at the downstream ends of the investigated reaches (degraded = D; first restored $=\mathrm{R} 1$; second restored $=\mathrm{R} 2$ ) and for the combined reaches R1 + R2 of the river Ruhr in summer 2014. Vertical grey bars indicate peak flow events. 
the river's habitat and hydrodynamic heterogeneity. Together, these changes may stimulate ecosystem metabolism, i.e., whole-stream rates of GPP and ER, as well as affect the river's metabolic balance. Increases in river metabolism, in turn, may result in increased rates of other ecosystem processes, such as secondary productivity and whole-stream nutrient processing (Fellows et al., 2006; Gücker and Pusch, 2006).

\subsection{Hydromorphological characteristics}

Recent monitoring and evaluation of restoration projects report positive effects on hydromorphology and habitat composition (Jähnig et al., 2009, 2010; Poppe et al., 2016). Similarly, we found greater habitat complexity of restored reaches, as indicated by wider and more diverse river channels. The reach with the highest restoration effort (R2) was characterized by the highest values and heterogeneity of hydromorphological variables; this suggests that restoration effort is indeed crucial for restoration success. According to Lorenz et al. (2012), the success of restoration in mid-sized to larger rivers can also be indicated by increased cover, abundance and diversity of macrophytes as they benefit from more natural and diverse substrate, and the variability in flow. Consequently, the higher share of macrophyte cover of total wetted area in R2 also highlighted the higher morphological quality of this reach.

Moreover, there were no point sources or changes in land use along the studied river section, and therefore increases in $\mathrm{P}$ and $\mathrm{N}$ concentrations and associated eutrophication effects in the studied river section seem unlikely (compare Table 1). Thus, higher macrophyte biomass and metabolic responses are likely to be a result of river restoration, i.e., wider channels increasing light availability, shallower channels providing better habitats for macrophytes, and lower current velocities decreasing hydraulic stress.

Changes in hydromorphology and habitat composition influenced hydrodynamics: we observed lower current velocity, higher longitudinal dispersion and larger transient storage zones in the restored reaches. This corresponds with the larger river width and wetted channel area, and the increased abundance of morphological features such as woody debris, islands and macrophyte patches. However, $F_{\text {med }}{ }^{200}$, i.e., the relative importance of transient storage for whole-stream hydrodynamics, was highest in R1 and lowest in R2, with intermediate values for $\mathrm{D}$. Accordingly, there appeared to be an inverse relationship between $F_{\text {med }}{ }^{200}$ and the share of macrophyte cover of total wetted area, which was highest in $\mathrm{R} 2$ and lowest in R1, with intermediate values in D. These findings suggest that the dense stands of macrophytes in R2 particularly altered stream hydrodynamics: macrophyte patches built large surface transient storage areas and potentially changed the locations of transient storage zones from the hyporheic zone to the surface water column. Macrophyte fields in R2 may have even been so dense that large parts of them were representing hydrodynamic dead zones. A similar effect was found in streams restored by implementing steering structures to enhance stream quality: the restored reaches were dominated by surface transient storage exchange (Becker et al., 2013). Furthermore, the sedimentation of fine sediment within dense macrophyte stands may further decrease exchange with the hyporheic zone.

\subsection{Functional characteristics}

Metabolism was measured over a 50-day period to obtain representative data, allowing for comparisons among sampling stations. Furthermore, this time series allowed for the analysis of environmental variability, such as flow peaks. The results were obtained for the summer period, i.e., the time of maximum biomass, which is also relevant for the WFD compliant sampling period (e.g., Haase et al., 2004; Schaumburg et al., 2004; EFI+ CONSORTIUM, 2009). Therefore, results obtained in this study are directly comparable to the river status derived from biological assessment.

In general, the three sampling stations showed similar patterns in metabolism, as our one-station metabolism approach measured a long upstream river section in addition to the experimental reaches. Rates of ER mirrored those of GPP, suggesting that autotrophic respiration largely drove temporal patterns in ER, despite an overall ratio of GPP: ER $<1$ and a slightly negative NEP during most of the measurement period. Similar patterns were found in streams in the US (Beaulieu et al., 2013; Hall et al., 2016). The average GPP : ER ratio was significantly higher downstream of the restored reaches in our study ( 0.86 and 0.97 , respectively) and in the combined restored reach (1.16) than in the upstream degraded river (0.66), indicating an increase in autotrophic processes following restoration. The only moderate heterotrophic state of the river together with ER closely tracking GPP indicated the importance of autochthonous production for the metabolism. This is further supported by the comparison of pre- and post-peak flow ER (Fig. 6). McTammany et al. (2003) suggested that higher inputs of allochthonous material may occur after flooding events, subsequently supporting high rates of ER. In line with this, we expected high rates of ER during the last third of the sampling period, especially in restored reaches with a potentially high particulate organic matter trapping efficiency. However, ER was lower compared to pre-flow peak conditions, with ER still mirroring GPP, thus indicating the coupling of autochthonous production with ER even after floods. This implies that restoration (reconnection of river and floodplain) did not increase resource transfer into the channel to such an extent that it influenced river metabolism.

We observed significantly higher GPP and ER at station $\mathrm{R} 2$ compared to the other stations. Metabolism of R1 did not markedly differ from $\mathrm{D}$, corresponding with consistently higher values of hydromorphological variables in R2 only. Given the previously discussed importance of autochthonous 
production for the metabolism, habitat enhancement supporting the growth of macrophytes is likely the cause for higher GPP and ER in R2. Consequently, only high restoration effort bringing a restored reach close to reference conditions led to pronounced effects on ecosystem metabolism. Restoration effects were mainly related to the growth of aquatic macrophytes, which formed dense stands that augmented ecosystem metabolism. We acknowledge that metabolism was measured during summer, i.e., the time of maximum biomass of aquatic macrophytes. Therefore, high GPP and ER measured in this campaign might be restricted to this season and effects will be lower during winter times when macrophyte abundance will be low.

Ecosystem metabolism of the sampling stations at the restored reaches and of the combined restored river reaches was expected to be at similar levels to those of natural rivers reported in the literature. Therefore, we compared GPP and ER of our sampling stations to those of rivers comparable in size (discharge between 5 and $50 \mathrm{~m}^{3} \mathrm{~s}^{-1}$; see Sects. S4, S5). GPP and ER estimated in this study were among the highest values reported for similar sized rivers, especially those of the sampling station R2 and the combined restored reach. Of all the rivers, for which metabolism has been reported, the channelized river Thur (Uehlinger, 2006) is closest to the Ruhr regarding size, sediment, and region. Interestingly, average GPP and ER reported for the Thur were similar to those of the channelized sampling station D. Thus, relatively low GPP and ER in hydromorphologically altered rivers compared to natural ones may be common. However, there is a tremendous variability in ecosystem metabolism among natural river reaches in the literature (see Sects. S4, S5). Considering the limited knowledge about natural geographical gradients in river metabolism, it was not possible to assess whether values obtained for restored reaches indicate natural conditions in a broader geographic context. In future analyses of restoration effects on fluvial metabolism, local reference conditions should therefore be assessed whenever possible.

Our experimental reaches reflected typical spatial scales on which restoration measures are implemented. However, individually, these reaches were too short to feasibly use the two-station diel DO change method (see Sect. 2.5). Accordingly, we used the one-station approach to assess reachscale restoration effects on ecosystem metabolism of longer river sections $(>10 \mathrm{~km})$. Following methods in Demars et al. (2015), we evaluated to what extent these metabolism estimates reflected the restored river sections. Measurements at sampling station R1 and R2 had only 16 and $24 \%$ influence, respectively, from the restored experimental reaches directly upstream. However, station R2 had 35\% influence from the combined reaches $\mathrm{R} 1+\mathrm{R} 2$, and thus $65 \%$ from upstream degraded river sections. Despite this mismatch between lengths of river reaches evaluated and reaches exclusively affected by restoration, we found significant effects of reach-scale restoration on whole-river metabolism. Interest- ingly, our study therefore also shows that high restoration effort in short river reaches ( 1 to $2 \mathrm{~km}$ ) had considerable effects on total whole-river metabolic rates of river stretches exceeding the length of the actually restored reaches $(>10 \mathrm{~km})$, and that the one-station method may therefore be an interesting option to qualitatively assess restoration effects in field situations, in which the two-station method is not feasible.

To quantitatively support these qualitative findings, we estimated metabolism of the combined restored reaches $\mathrm{R} 1+\mathrm{R} 2$, which were long enough to permit the application of the two-station method. The obtained metabolic rates should be directly comparable to metabolic rates of the upstream, degraded river (measured at station D with the onestation method) as results obtained with the one-station and the two-station methods often agree remarkably well (e.g., Bernot et al., 2010; Beaulieu et al., 2013). The total restored reach $(\mathrm{R} 1+\mathrm{R} 2)$ showed higher GPP, ER, NEP, and GPP : ER than the upstream degraded river. Thus, these results support the findings derived from the one-station method, indicating an increase in the river's metabolism and metabolic balance associated with restoration.

Thus, the restoration of short river reaches may have positive effects on downstream river sections regarding diel DO variability and carbon spiraling. High rates of metabolism and the occurrence of dense macrophyte stands in restored river reaches may also increase the assimilation of dissolved nutrients (Fellows et al., 2006; Gücker et al., 2006) and the sedimentation of particulate nutrients (Schulz and Gücker, 2005), thereby positively affecting water quality.

\subsection{Recommendations for restoration monitoring}

For most regions and river types, data are missing that could be used to establish limits of good, moderate, or poor river conditions. However, based on data from mainly small streams, Young et al. (2008) proposed a useful framework to assess functional stream health using GPP, ER, NEP, and GPP:ER. Consequently, metabolic rates for different river types should be surveyed to allow the incorporation of ecosystem metabolism of mid-sized and large rivers as a functional indicator in this framework. Our study stresses the benefits of metabolism as a functional indicator complementing the monitoring of restoration projects (compare Young et al., 2008; Bunn et al., 2010): Temporally high-resolution and automated monitoring that integrates biotic and abiotic variables over time and across habitats may increase our understanding of the effects of river restoration and might help identifying initial changes after restoration. Incorporating functional indicators into monitoring programs may enable a more holistic assessment of river ecosystems and elucidate responses to restoration (and also impairment), which may be related to ecosystem structure and function. 
Data availability. Data for this paper can be found in the Supplement.

\section{The Supplement related to this article is available online at doi:10.5194/bg-14-1989-2017-supplement.}

Competing interests. The authors declare that they have no conflict of interest.

Acknowledgements. We thank D. Dangel, K. Gees, M. Gies, A. Gieswein, K. Kakouei, B. Rieth, L. Rothe, C. Sondermann, M. Sondermann, and colleagues from the Ruhr University Bochum for their help during the tracer experiment. We thank L. Wenning and J. Herold for their assistance in many of our field trips, R. Dietz and D. Hammerschmidt for supporting our research, and the NZO GmbH for providing aerial photos. We thank B. Demars for helpful comments on a previous version of this manuscript. We also gratefully acknowledge a $\mathrm{PhD}$ fellowship of the German Environment Foundation (Deutsche Bundesstiftung Umwelt, DBU) to Benjamin Kupilas and a productivity grant by the Brazilian National Council for Scientific and Technological Development (CNPq 302280/2015-4) to Björn Gücker. This study was financially supported by the EU-funded project REFORM (Restoring rivers FOR effective catchment Management), European Union's Seventh Programme for research, technological development and demonstration under grant agreement no. 282656.

Edited by: T. J. Battin

Reviewed by: three anonymous referees

\section{References}

Almeida, G. H., Boëchat, I. G., and Gücker, B.: Assessment of stream ecosystem health based on oxygen metabolism: Which sensor to use?, Ecol. Eng., 69, 134-138, 2014.

Beaulieu, J. J., Arango, C. P., Balz, D. A., and Shuster, W. D.: Continuous monitoring reveals multiple controls on ecosystem metabolism in a suburban stream, Freshwater Biol., 58, 918-937, 2013.

Becker, J. F., Endreny, T. A., and Robinson, J. D.: Natural channel design impacts on reach-scale transient storage, Ecol. Eng., 57, 380-392, 2013

Beisel, J.-N., Usseglio-Polatera, P., and Moreteau, J.-C.: The spatial heterogeneity of a river bottom: a key factor determining macroinvertebrate communities, Hydrobiologia, 422/423, 163$171,2000$.

Bernhardt, E. S., Palmer, M. A., Allan, J. D., Alexander, G., Barnas, K., Brooks, S., Carr, J., Clayton, S., Dahm, C., Follstad-Shah, J., Galat, D., Gloss, S., Goodwin, P., Hart, D., Hassett, B., Jenkinson, R., Katz, S., Kondolf, G. M., Lake, P. S., Lave, R., Meyer, J. L., O’Donnell, T. K., Pagano, L., Powell, B., and Sudduth, E.: Ecology - synthesizing US river restoration efforts, Science, 308 , 636-637, 2005.

Bernot, M. J., Sobota, D. J., Hall, R. O., Mulholland, P. J., Dodds, W. K., Webster, J. R., Tank, J. L., Ashkenas, L. R., Cooper, L.
W., Dahm, C. N., Gregory, S. V., Grimm, N. B., Hamilton, S. K., Johnson, S. L., McDowell, W. H., Meyer, J. L., Peterson, B., Poole, G. C., Valett, H. M., Arango, C., Beaulieu, J. J., Burgin, A. J., Crenshaw, C., Helton, A. M., Johnson, L., Merriam, J., Niederlehner, B. R., O’Brien, J. M., Potter, J. D., Sheibley, R. W., Thomas, S. M., and Wilson, K.: Inter-regional comparison of land-use effects on stream metabolism. Freshwater Biol., 55, 1874-1890, 2010.

Bunn, S. E., Abal, E. G., Smith, M. J., Choy, S. C., Fellows, C. S., Harch, B. D., Kennard, M. J., and Sheldon, F.: Integration of science and monitoring of river ecosystem health to guide investments in catchment protection and rehabilitation, Freshwater Biol., 55, 223-240, 2010.

Chapra, S. C. and Di Toro, D. M.: Delta method for estimating primary production, respiration, and reaeration in streams, J. Environ. Eng., 117, 640-655, 1991.

Colangelo, D. J.: Response of river metabolism to restoration of flow in the Kissimmee River, Florida, U.S.A., Freshwater Biol., 52, 459-470, 2007.

Demars, B. O. L., Thompson, J., and Manson, J. R.: Stream metabolism and the open diel oxygen method: Principles, practice, and perspectives, Limnol. Oceanogr.-Meth., 13, 356-374, 2015.

Dodds, W. K., Veach, A. M., Ruffing, C. M., Larson, D. M., Fischer, J. L., and Costigan, K. H.: Abiotic controls and temporal variability of river metabolism: multiyear analyses of Mississippi and Chattahoochee River data, Freshwater Science, 32, 1073-1087, 2013.

Ecke, F., Hellsten, S., Köhler, J., Lorenz, A. W., Rääpysjärvi, J., Scheunig, S., Segersten, J., and Baattrup-Pedersen, A.: The response of hydrophyte growth forms and plant strategies to river restoration, Hydrobiologia, 769, 41-54, 2016.

EEA (European Environment Agency): European Waters - Assessment of Status and Pressures, EEA Report No. 8, EEA, Copenhagen, 96 pp., 2012.

EFI+ CONSORTIUM: Manual for the application of the new European Fish Index - EFI+, A fish-based method to assess the ecological status of European running waters in support of the Water Framework Directive, available at: http://efi-plus.boku.ac.at/ software/doc/EFI+Manual.pdf (last access: 30 September 2016), 2009.

Fellows, C. S., Valett, H. M., and Dahm, C. N.: Whole-stream metabolism in two montane streams: Contribution of the hyporheic zone, Limnol. Oceanogr., 46, 523-531, 2001.

Fellows, C. S., Valett, H. M., Dahm, C. N., Mulholland, P. J., and Thomas, S. A.: Coupling nutrient uptake and energy flow in headwater streams. Ecosystems, 9, 788-804, 2006.

Flores, L., Larranaga, A., Dìez, J., and Elosegi, A.: Experimental wood addition in streams: effects on organic matter storage and breakdown, Freshwater Biol., 56, 2156-2167, 2011.

Friberg, N., Baattrup-Pedersen, A., Kristensen, E. A., Kronvang, B., Larsen, S. E., Pedersen, M. L., Skriver, J., Thodsen, H., and Wiberg-Larsen, P.: The Gelsa River Restoration Revisited: community persistence of the macroinvertebrate community over an 11-year period, Ecol. Eng., 66, 150-157, 2014.

Gellert, G., Pottgiesser, T., and Euler, T.: Assessment of the structural quality of streams in Germany - basic description and current status, Environ. Monit. Assess., 186, 3365-3378, 2014. 
Göthe, E., Timmermann, A., Januschke, K., and Baattrup-Pedersen, A.: Structural and functional responses of floodplain vegetation to stream ecosystem restoratio, Hydrobiologia, 769, 79-92, 2016.

Gücker, B. and Boëchat, I. G.: Stream morphology controls ammonium retention in tropical headwaters, Ecology, 85, 2818-2827, 2004.

Gücker, B. and Pusch, M. T.: Regulation of nutrient uptake in eutrophic lowland streams, Limnol. Oceanogr., 51, 1443-1453, 2006.

Gücker, B., Brauns, M., and Pusch, M. T.: Effects of wastewater treatment plant discharge on ecosystem structure and function of lowland streams, J. N. Am. Benthol. Soc., 25, 313-329, 2006.

Gücker, B., Boëchat, I. G., and Giani, A.: Impacts of agricultural land use on ecosystem structure and whole-stream metabolism of tropical Cerrado streams, Freshwater Biol., 54, 2069-2085, 2009.

Haase, P., Lohse, S., Pauls, S., Schindehütte, K., Sundermann, A., Rolauffs, P., and Hering, D.: Assessing streams in Germany with benthic invertebrates: development of a practical standardised protocol for macroinvertebrate sampling and sorting, Limnologica, 34, 349-365, 2004.

Haase, P., Hering, D., Jähnig, S. C., Lorenz, A. W., and Sundermann, A.: The impact of hydromorphological restoration on river ecological status: A comparison of fish, benthic invertebrates, and macrophytes, Hydrobiologia, 704, 475-488, 2013.

Hall, R. O., Yackulic, C. B., Kennedy, T. A., Yard, M. D., RosiMarshall, E. J., Voichick, N., and Behn, K. E.: Turbidity, light, temperature, and hydropeaking control daily variation in primary production in the Colorado River, Grand Canyon, Limnol. Oceanogr., 60, 512-526, 2015.

Hall, R. O., Tank, J. L., Baker, M. A., Rosi-Marshall, E. J., and Hotchkiss, E. R.: Metabolism, Gas Exchange, and Carbon Spiraling in Rivers, Ecosystems, 19, 73-86, 2016.

Harvey, J. V. and Wagner, B. J.: Quantifying hydrologic interaction between streams and their subsurface hyporheic zones, in: Streams and Ground Waters, edited by: Jones, J. B. and Mulholland, P. J., 3-44, Academic Press, San Diego, CA, 2000.

Hering, D., Aroviita, J., Baattrup-Pedersen, A., Brabec, K., Buijse, T., Ecke, F., Friberg, N., Gielczewski, M., Januschke, K., Köhler, J., Kupilas, B., Lorenz, A. W., Muhar, S., Paillex, A., Poppe, M., Schmidt, T., Schmutz, S., Vermaat, J., Verdonschot, P. F. M., Verdonschot, R. C. M., Wolter, C., and Kail, J.: Contrasting the roles of section length and instream habitat enhancement for river restoration success: a field study on 20 European restoration projects, J. Appl. Ecol., 50, 97-106, 2015.

Jähnig, S. C., Brunzel, S., Gacek, S., Lorenz, A. W., and Hering, D.: Effects of re-braiding measures on hydromorphology, floodplain vegetation, ground beetles and benthic invertebrates in mountain rivers, J. Appl. Ecol., 46, 406-416, 2009.

Jähnig, S. C., Brabec, K., Buffagni, A., Erba, S., Lorenz, A. W., Ofenböck, T., Verdonschot, P. F. M., and Hering, D.: A comparative analysis of restoration measures and their effects on hydromorphology and benthic invertebrates in 26 central and southern European rivers, J. Appl. Ecol., 47, 671-680, 2010.

Januschke, K. and Verdonschot, R. C. M.: Effects of river restoration on riparian ground beetles (Coleoptera: Carabidae) in Europe, Hydrobiologia, 769, 93-104, 2016.
Januschke, K., Jähnig, S. C., Lorenz, A. W., and Hering, D.: Mountain river restoration measures and their success(ion): effects on river morphology, local species pool, and functional composition of three organism groups, Ecol. Indic., 38, 243-255, 2014.

Kohler, A.: Methoden der Kartierung von Flora und Vegetation von Süßwasserbiotopen. Landschaft und Stadt, 10, 73-85, 1978.

Kohler, A. and Janauer, G.: Zur Methodik der Untersuchung von aquatischen Makrophyten in Fließgewässern, in: Handbuch Angewandte Limnologie, edited by: Steinberg, C., Bernhardt, H., and Klapper, H., 1-22, ecomed Verlagsgesellschaft, Landsberg, 1997.

Kupilas, B., Friberg, N., McKie, B. G., Jochmann, M. A., Lorenz, A. W., and Hering, D.: River restoration and the trophic structure of benthic invertebrate communities across 16 European restoration projects, Hydrobiologia, 769, 105-120, 2016.

Lepori, F., Palm, D., and Malmqvist, B.: Effects of stream restoration on ecosystem functioning: detritus retentiveness and decomposition, J. Appl. Ecol., 42, 228-238, 2005.

Lepori, F., Gaul, D., Palm, D., and Malmqvist, B.: Food-web responses to restoration of channel heterogeneity in boreal streams, Can. J. Fish. Aquat. Sci., 63, 2478-2486, 2006.

Lorenz, A. W., Korte, T., Sundermann, A., Januschke, K., and Haase, P.: Macrophytes respond to reach-scale river restorations, J. Appl. Ecol., 49, 202-212, 2012.

Marzolf, E. R., Mulholland, P. J., and Steinman, A. D.: Improvements to the diurnal upstream-downstream dissolved-oxygen change technique for determining whole stream metabolism in small streams, Can. J. Fish. Aquat. Sci., 51, 1591-1599, 1994.

McTammany, M. E., Webster, J. R., Benfield, E. F., and Neatrour, M. A.: Longitudinal patterns of metabolism in a southern Appalachian river, J. N. Am. Benthol. Soc., 22, 359-370, 2003.

Mulholland, P. J., Fellows, C. S., Tank, J. L., Grimm, N. B., Webster, J. R., Hamilton, S. K., Martí, E., Ashkenas, L., Bowden, W. B., Dodds, W. K., McDowell, W. H., Paul, M. J., and Peterson, B. J.: Inter-biome comparison of factors controlling stream metabolism, Freshwater Biol., 46, 1503-1517, 2001.

Odum, H. T.: Primary production in flowing waters, Limnol. Oceanogr., 2, 102-117, 1956.

Palmer, M. A. and Filoso, S.: Restoration of ecosystem services for environmental markets, Science, 325, 575-576, 2009.

Palmer, M. A., Hondula, K. L., and Koch, B. J.: Ecological restoration of streams and rivers: shifting strategies and shifting goals, Annu. Rev. Ecol. Evol. S., 45, 247-269, 2014.

Poppe, M., Kail, J., Aroviita, J., Stelmaszczyk, M., Giełczewski, M., and Muhar, S.: Assessing restoration effects on hydromorphology in European mid-sized rivers by key hydromorphological parameters, Hydrobiologia, 769, 21-40, 2016.

R Development Core Team: R: A language and environment for statistical computing, R Foundation for Statistical Computing, Version 3.2.2, Vienna, Austria, available at: http://www.R-project. org, 2007.

Reichert, P., Uehlinger, U., and Acuña, V.: Estimating stream metabolism from oxygen concentrations: effect of spatial heterogeneity, J. Geophys. Res.-Biogeo., 114, G03016, doi:10.1029/2008JG000917, 2009.

Roberts, B. J., Mulholland, P. J., and Hill, W.R.: Multiple scales of temporal variability in ecosystem metabolism rates: results from 2 years of continuous monitoring in a forested headwater stream, Ecosystems, 10, 588-606, 2007. 
Roley, S. S., Tank, J. L., Griffiths, N. A., Hall, R. O., and Davis, R. T.: The influence of floodplain restoration on whole-stream metabolism in an agricultural stream: insights from a 5-year continuous data set, Freshwater Science, 33, 1043-1059, 2014.

Roni, P., Hanson, K., and Beechie, T.: Global review of the physical and biological effectiveness of stream habitat rehabilitation techniques, N. Am. J. Fish. Manage., 28, 856-890, 2008.

Runkel, R. L.: One-dimensional transport with inflow and storage (OTIS): A solute transport model for streams and rivers. US Geological Survey, Water-Resources Investigation Report 98-4018, Denver, CO, available at: http://co.water.usgs.gov/otis (last access: 23 July 2016), 1998.

Runkel, R. L.: A new metric for determining the importance of transient storage, J. N. Am. Benthol. Soc., 21, 529-543, 2002.

Schaumburg, J., Schranz, C., Foerster, J., Gutowski, A., Hofmann, G., Meilinger, P., Schneider, S., and Schmedtje, U.: Ecological classification of macrophytes and phytobenthos for rivers in Germany according to the Water Framework Directive, Limnologica, 34, 283-301, 2004.

Schaumburg, J., Schranz, C., Meilinger, P., Stelzer, D., Hofmann, G., Foerster, J., Gutowski, A., Schneider, S., Köpf, B., and Schmedtje, U.: Makrophyten und Phytobenthos in Fließgewässern und Seen - Das deutsche Bewertungsverfahren: Entwicklung, Praxistest und Ausblick, Limnologie aktuell, 11, 63-75, 2005a.

Schaumburg, J., Schranz, C., Stelzer, D., Hofmann, G., Gutowski, A., and Foerster, J.: Bundesweiter Test: Bewertungsverfahren "Makrophyten \& Phytobenthos" in Fließgewässern zur Umsetzung der WRRL, Bayerisches Landesamt für Umwelt, München, 2005b.

Schmutz, S., Jurajda, P., Kaufmann, S., Lorenz, A. W., Muhar, S., Paillex, A., Poppe, M., and Wolter, C.: Response of fish assemblages to hydromorphological restoration in central and northern European rivers, Hydrobiologia, 769, 67-78, 2016.

Schröder, M., Kiesel, J., Schattmann, A., Jähnig, S. C., Lorenz, A. W., Kramm, S., Keizer-Vlek, H., Rolauffs, P., Graf, W., Leitner, P., and Hering, D.: Substratum associations of benthic invertebrates in lowland and mountain streams. Ecol. Indic., 30, 178189, 2013.

Schulz, M. and Gücker, B.: Macrophytes increase spatial patchiness of fluvial sedimentary records and effect temporal particulate nutrient storage, Aquat. Geochem., 11, 89-107, 2005.

Silva-Junior, E. F., Moulton, T. P., Boëchat, I. G., and Gücker, B.: Leaf decomposition and ecosystem metabolism as functional indicators of land use impacts on tropical streams, Ecol. Indic., 36, 195-204, 2014.
Strayer, D. L. and Dudgeon, D.: Freshwater biodiversity conservation: recent progress and future challenges. Journal of the North American Benthological Society, 29, 344-358, 2010.

Tank, J. L., Rosi-Marshall, E. J., Griffiths, N. A., Entrekin, S. A., and Stephen, M. L.: A review of allochthonous organic matter dynamics and metabolism in streams, J. N. Am. Benthol. Soc., 29, 118-146, 2010.

UBA (Federal Environment Agency): Water Resource Management in Germany Part 1: Fundamentals, Bonn, available at: https:/www.umweltbundesamt.de/sites/default/files/medien/ 378/publikationen/wawi_teil_01_englisch_barrierefrei.pdf (last access: 25 November 2016), 2013.

Uehlinger, U.: Resistance and resilience of ecosystem metabolism in a flood-prone river system, Freshwater Biol., 45, 319-332, 2000.

Uehlinger, U.: Annual cycle and inter-annual variability of gross primary production and ecosystem respiration in a floodprone river during a 15-year period, Freshwater Biol., 51, 938-950, 2006.

Valett, H. M., Morrice, J. A., Dahm, C. N., and Campana, M. E.: Parent lithology, surface-groundwater exchange, and nitrate retention in headwater streams, Limnol. Oceanogr., 41, 333-345, 1996.

Verdonschot, R. C. M., Kail, J., McKie, B. G., and Verdonschot, P. F. M.: The role of benthic microhabitats in determining the effects of hydromorphological river restoration on macroinvertebrates, Hydrobiologia, 769, 55-66, 2016.

Young, R. G. and Huryn, A. D.: Comment: improvements to the diurnal upstream-downstream dissolved oxygen change technique for determining whole stream metabolism in small streams, Can. J. Fish. Aquat. Sci., 55, 1784-1785, 1998.

Young, R. G. and Huryn, A. D.: Effects of land use on stream metabolism and organic matter turnover, Ecol. Appl., 9, 13591376, 1999.

Young, R. G., Matthaei, C. D., and Townsend, C. R.: Organic matter breakdown and ecosystem metabolism: functional indicators for assessing river ecosystem health, J. N. Am. Benthol. Soc., 27, 605-625, 2008. 